\author{
G.B. Madiyeva* (iD), A.K. Karaman \\ Al-Farabi Kazakh National University, Kazakhstan, Almaty, \\ *e-mail: gbmadiyeva.kz@gmail.com

\section{ENGLISH ANTHROPONYMS: THEIR FEATURES AND USAGE AS A LINGUISTIC RESOURCE}

The article touches upon the teaching a foreign language in secondary schools is a communicative orientation. Knowledge gained in the course of acquaintance with such a narrow topic as "anthroponyms in English" contributes to a more conscious approach to the process of learning English and can help the student to be more interested in the work process. As it is known, anthroponyms have a special place in any culture, including English, so it is imperative to know their use in speech, since it is difficult to imagine communication without proper names. At present, it can be stated that anthroponymics has an interdisciplinary nature, since it unites not only linguistic paradigms, but also a number of other areas of science: cultural studies, history, ethnography, sociology, psychology, and others. This factor is due to the specify of this linguistic concept from the grammatical, semantic, historical, cultural and psychological points of view. This article examines the concept of anthroponym and its main characteristics. In this regard, the use of anthroponyms in classrooms allows not only to motivate students to the language, but also to learn the culture of native speakers. Consequently, anthroponyms are one of the most significant linguistic resources for the development of educational assignments, scientific projects on various linguistic topics of mastering the English language. The practical significance of the study lies in the fact that its results can be applicable both in the practice of using English anthroponymic dictionaries and in their compilation.

Key words: antroponym, onym, mythonym, onomasticon, proper name, linguistic resource, teaching a foreign language.

\author{
Г.Б. Мадиева*, А.Қ. Қараман \\ Әл-Фараби атындағы Қазақ ұлттық университеті, Қазақстан, Алматы қ., \\ *e-mail: gbmadiyeva.kz@gmail.com \\ Шет тілінің антропонимдері: ерекшеліктері \\ және тілдік қор ретінде қомданылуы
}

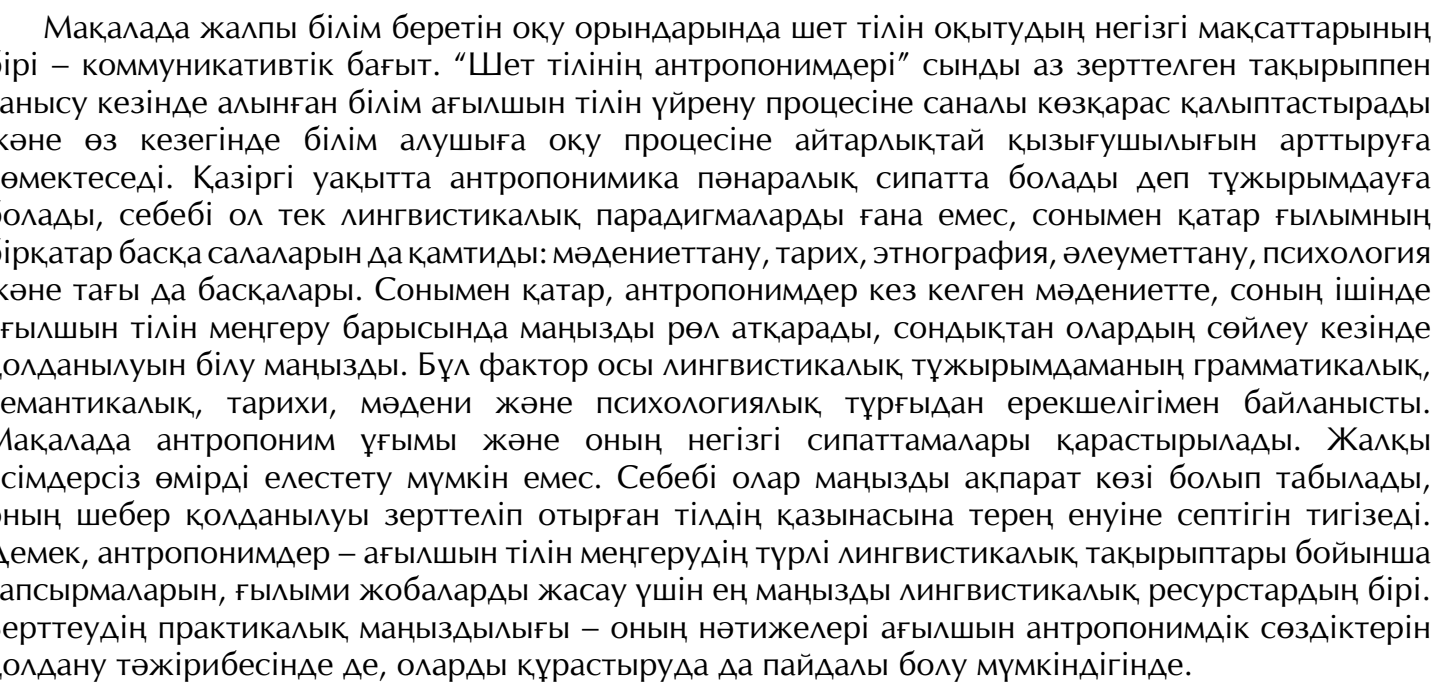

Түйін сөздер: антропоним, оним, жалқы есім, мифоним, ономастикон, тілдік қор, шет тілін оқыту. 


\author{
Г.Б. Мадиева*, А.К. Караман \\ Казахский национальный университет имени аль-Фараби, Казахстан, г. Алматы, \\ ${ }^{*}$ e-mail: gbmadiyeva.kz@gmail.com \\ Английские антропонимы: свойства и \\ их использование в качестве языкового ресурса
}

\begin{abstract}
В статье рассматриваются основные цели обучения иностранному языку в общеобразовательных школах - коммуникативная направленность. Компетенции, полученные в ходе знакомства с такой узкой, но важной темой, как “антропонимы в английском языке", способствуют более осознанному подходу к процессу изучения английского языка и могут, в свою очередь, повысить заинтересованность ученика иностранным языком. В настоящее время можно констатировать, что антропонимика имеет междисциплинарный характер, поскольку объединяет не только мингвистические парадигмы, но и ряд Аругих сфер науки: культурологию, историю, этнографию, социологию, психологию и Аругие. Как известно, антропонимы играют важную роль в Аюбой культуре, в том числе и в английской, поэтому крайне необходимо знать их использование в речи, поскольку трудно представить коммуникацию без имён собственных. Этот фактор связан с особенностями Аанного Аингвистического понятия в грамматическом, семантическом, историческом, культурном, психологическом аспектах. В связи с этим использование антропонимов на учебных занятиях позволяет не только мотивировать учащихся к познанию языка, но и познать культуру носителей языка. Следовательно, антропонимы являются одним из значимых языковых ресурсов Аля разработки учебных заданий, научных проектов по различным лингвистическим темам усвоения английского языка. Практическая значимость исследования заключается в том, что его результаты могут быть продуктивными как в практике использования английских антропонимических словарей, так и при их составлении.

КАючевые слова: антропоним, оним, мифоним, ономастикон, имя собственное, языковой ресурс, преподавание иностранного языка.
\end{abstract}

\section{Introduction}

Anthroponyms play a special role in the context of the study of foreign languages. The most interesting for the analysis is their position in the framework of acquaintance with English as a foreign language.

For a better understanding of the origin of English proper names, as in the culture of other peoples, one should turn to the history of the emergence of the English-speaking countries themselves. So, the first settlers of the British Isles are considered Anglo-Saxons. The anthroponymy system of the Anglo-Saxons was quite simple: it contained a single integral nominal part - the first name. By now, almost all Anglo-Saxon names have fallen out of use (Searle W. G., 2011: 662).

The Celtic tribes that organized the invasions of the British Isles around AD 700 communicated in various "dialects". The names of the most ancient origin mainly denoted the qualities of their carriers, described the character, compared the referent with animals or natural phenomena. Arthur - "strong as a bear", Kevin - "gentle", Eden - "rich" and etc (Ekwall E.,1947: 207).

Looking at the basics of personal names in different peoples, we can find typological similarity, which is probably the result of borrowing, mutual influence, of names of different language systems and the result of similar independent development. This similarity is found in two aspects: in the use of the same parts of speech in their formation, and in the use of words of certain lexical fields for this purpose. As S.I. Garagulya notes, the subclass of personal names is constantly updated, and subject to the same dynamic processes of development, reinterpretation, and metaphorization as the class of names in general (Garagulya S.I., 2010: 126). As a consequence, one of the priority problems in the field of onomastics is the study of the origin and development of proper names. One of the topical issues of modern anthroponymy is the structural and linguistic specificity of a personal name, which implies its difference from other onomastic categories, such as: toponymy, zoonymy, astronomy, ethnonomy, and others, as well as the difference from a common name.

\section{Experiment}

Researchers in the field of anthroponymy are called anthroponymists. Since the study of anthroponyms is also relevant for several other disciplines within social sciences and humanities, experts from those disciplines also take part in anthroponymic studies, including researchers from the fields of anthropology. After the Norman invasion, Old English names gradually began to lose their popularity, and 
they were replaced by onomastic constructions borrowed from the French language. Names such as Richard, Robert, William, Hugo, as well as names of biblical origin - Thomas, John and Peter - began to be used in the naming system more and more. The most intensive assimilation of names with "Old French" roots took place in the ruling circles and the upper strata of society.

The next period, which can also be identified as a turning point in the history of anthroponymy, is the Renaissance. Vanessa (the heroine of the poem "Cadenus and Vanessa" by Jonathan Swift), Stella and Pamela (characters in the novels and sonnets of Philip Sydney), as well as many names from the novels of Walter Scott - Amy, Lancelot, Nigel have become popular in society not only as fictitious names literary heroes but also as names of people in real life (Windt B., 2005: 43-63).

The Puritans invented "divine" names - Faith, Hope, Ashes, Delivery, Joy Again, Praise-God however, more euphonious names and less similar to common nouns were also found among them Abraham, Banjamin, Elihu, Isaac, Samuel. It is the last group of names that is still considered quite common in the United States of America (Gasque Th. J., 2010: 87-106).

Based on the study of the material on the origin of English-language names, we can draw the following conclusions about the ways of their appearance in the language:

1. first, onyms are concepts obtained through the use of associative thinking. It turns out that many anthroponyms are obtained due to the semantic transition of common nouns into proper names;

2. secondly, new proper names in the language system may appear in the course of borrowing already existing names from another language system;

3 . and, thirdly, the onomasticon (or nominal fund) will expand due to the invention of new names, based on the existing lexical system of the native language.

The modern "nominal fund" of English-speaking countries is a collaboration of historically conditioned onyms with actual anthroponyms, invented in our time using various word-formation processes. And it is important to note that the modern English anthropogenic system is also greatly influenced by changes in both the social system and, for example, the class structure in the countries of the target language.

In a speech context, proper names are used quite often. For example in fiction $2.5-3 \%$ of the entire narrative is occupied by anthroponyms. Names are used more often in everyday communication.
The English full name is compound, as it can include several components, for example, Jack London, Rudyard Kipling (full name - Joseph Rudyard Kipling), Agatha Mary Clarissa Miller (later Christie - Agatha Mary Clarissa Chrisite) or Francis Scott Fitzgerald (whose full name consisted of four parts, not three, as is commonly believed - Francis Scott Key Fitzgerald).

Little attention is paid to anthroponyms as a specific linguistic category in the course of studying educational material. This opinion is completely subjective, therefore, in order to objectively assess the role of onyms in the learning process, one should remember where students can meet this topic in the educational process (Siefring J., 2004: 340).

The most important role we are considering proper names - anthroponyms - play in the study of philological subjects - history, literature, foreign languages. In the first case, a high concentration of proper names falls on the names of specific individuals who left their mark on the development and formation of a particular state. Historical proper names simply call certain individuals, and their use only employs students' skills of comprehension, memorization and assimilation. Additional analysis should not be carried out when encountering personal names in history lessons.

When teaching English, onyms play an important role, activating students' skills of comprehension, memorization and assimilation. In the process of studying this subject, mastering of correctly built primary systematized processes of speech, reading and writing is carried out. The development of the ability to use the knowledge gained - the ability to grammatically, phonetically and punctually correctly build speech, based on the necessary language rules - is the main task of a teacher of a foreign language. As an assistant in the process of mastering any of the mentioned skills, you can use examples from the system of English anthroponymy.

For example, the names Baz, Pat, Tess, Adam, Jig, at first glance, are the simplest examples of onyms. However, let us pay attention to the fact that when using these names in speech, the child unconsciously learns various ways of pronouncing sounds. He subconsciously analyzes the difference in the pronunciation of the explosive phoneme [b] in the name Baz and his voiceless pair [p] used in the onym Pat; the difference between stressed and unstressed vowels in the name Adam, which, it turns out, depending on the position in the word, can sound like an open sound [æ] in the first case and unstressed $[\partial]$ in the second. Schoolchildren learn to pronounce completely 
new sound signs that do not exist in their first language system.

Anthroponyms often appear as part of phraseological units in English lessons. The study of phraseological aspects of the language within the framework of one subject discipline also makes it possible to expand the student's knowledge in such areas as history and culture. Phraseological turns, which include proper names, always have a figurative meaning. Analysis and memorization of such linguistic units contribute to: a) expansion of the student's vocabulary; b) the development of the ability to analyze (since when studying phraseological units, one can invite students to first guess independently about the meaning hidden in the studied phraseological phrase); c) activation of meta subject connections in the learning process.

Often, in order to understand a particular speech turnover used in English, it is necessary to refer to its origin. For example, translating Joe Miller's personal name may not be an easy task. In modern English, the use of this anthroponym means "to joke flatly", "to resort to a hackneyed anecdote" - "You're not so dull, to borrow a very old Joe Miller, when you're silent" ("And you're not that stupid, as the old joke says when you keep quiet"). To understand such a translation of a seemingly simple name, you need to know the fact that Joseph Miller was the first person to publish his collection of jokes in the 18th century and became the first famous comedian (Birch W. de Gray., 1964: 696).

As part of the school curriculum, the expansion of the stock of onomastic vocabulary contributes to the mastery of the studied discipline at the highest level. A detailed acquaintance with the system of personal names plays a favourable role in improving the language culture of schoolchildren, helps students to more easily operate with speech instruments, and also develops not only oral communication but also the written form.

The results obtained from the process of studying the system of English-language onyms in foreign language lessons and their detailed analysis suggest that after mastering the taught material, students will be able to operate with the received universal knowledge (informational, organizational, logical skills), which will allow them to continue the process of successful independent education.

The above possibility of a comprehensive study of onyms in the intersection of several academic disciplines only confirms the relevance of studying this linguistic direction in the practice of teaching compulsory educational material in secondary schools.
It turns out that the study of the science of anthroponyms once again proves the possibility of a more laconic fulfilment of educational tasks that the teacher sets himself when starting the learning process.

\section{Results and discussion}

The results of the analysis can be stated as follows: onomastics captures a wide range of issues and educational problems that it can solve. As a section of linguistic science is also responsible for the development of students' ability to communicate, successful interaction, for expanding the horizons and general awareness of schoolchildren about objects and phenomena of the surrounding world, the ability to conduct deep and detailed analysis and research using the inductive method. Questions directly related to the anthroponyms are found in the Olympiad tasks, which helps to develop the creative potential of students, and can also be used in work on a scientific project or in scientific research, which also contributes to the formation of high cognitive activity of the student.

For more effective work with students, the examples from the system of English anthroponymy should be used, which are suitable at any stage of learning English. Modern methodologists believe that an English lesson must necessarily begin with a small speech warm-up - "Warming-Up" (Gorbanevsky M.V., 1987:156). The teacher can invite students to memorize short rhymes in which English anthroponyms are used, and start each lesson by pronouncing them. In the course of this assignment, students under the supervision of an English teacher will improve their speaking skills and increase their knowledge of the phonetic side of the foreign language being studied. This technique is applicable to students at any level of general education schools.

For example, you can memorize this short children's song:

Little Tommy tittle mouse

Lived in a little house;

He caught fishes

In other men's ditches

This warm-up option is suitable for junior students (4th grade, for example) since the language of the song is quite simple and the general meaning is unpretentious. A short quatrain is used to train the correct pronunciation of the alveolar sounds $[t]$ and [1]. The task of the teacher, in this case, is to draw the attention of schoolchildren to the peculiarity of setting the language when reproducing the aforementioned phonemes, to explain to the students 
what "alveoli" are, and to consider in detail the differences in the sound between a dull sound $[t]$ and a voiced sonorant [1] - and English sounds. (Salimova D. A., 2008: 112).

The system of English anthroponymy is often used in conducting English lessons, starting with the use of the simplest names in the process of first acquaintance with a foreign language system and ending with the morphological, syntactic and grammatical analysis of onyms. Revealing hidden concepts, English proper names allow us to trace the formation of interdisciplinary connections of the English language with such academic disciplines as history, geography.

Anthroponyms in the lesson can be:

1. as part of a phraseological unit

(biblical + common nouns, mythonyms + common nouns, as well as persons of mixed type, who have lost the direct nominative and identifying the function of personal names and have passed into the category of common nouns);

2. as an important aspect of translation activities. When translating, students need to remember that proper names change their phonetic structure, sometimes they can acquire additional emotional significations, in connection with which it is necessary to pay attention to the context of the use of onyms;

3. in the role of a part of the speech warm-up, which trains students' speaking and communication skills. The simplest form of anthroponyms in such cases helps to pay more attention to the phonetic side of their use (Sattarov G.F., 1992: 240).

1) Speaking and pronunciation exercise

Some first names are easy to pronounce (e.g. Sally or Peter), but there are some which are difficult to pronounce correctly (e.g. Sean or Laura). And pronunciation of these words can appear in other words, that is why the following exercise is very helpful.

The teachers turn on the audio or pronounce names, and students have to spell the name correctly, then pronounce the names and give examples of the words that have the same spelling and pronunciation.

Some problems with spelling and finding the words with the same spelling and pronunciation can appear during making the exercise. However, it is natural, because students think that if the words have the same pronunciation of sounds, then they have to have the same spelling of these sounds. To solve this problem named exercise and other spelling exercises should be done more.

2) Grammar exercise

Anthroponyms are also helpful to practice grammar with children of primary school. As it is hard for them to make complicated sentences, English names will make setting sentences easier.

The teacher gives the list of names and tenses, students make sentences using anthroponyms and tenses practising grammar.

\section{Conclusion}

The work considered the specific type of the class "proper names" - anthroponyms - and their features in general, and the emphasis was placed on the onyms of English origin, their functions in speech and the role played by them in English lessons were also determined.

At the initial school stage, tasks for the spelling of anthroponyms, the study of the simplest Englishlanguage texts with the use of onyms in them, the use of personal names in basic communication and the construction of elementary dialogues between students are effective.

At the middle stage of learning, productive tasks in the study English using the anthroponymy system are considered: analysis of the phonetic component of onyms, the use of short English poems on the subject and tongue twisters in the classroom as a speech warm-up.

The use of anthroponym in English lessons contributes to an increase in the level of general literacy and culture of students. Teachers can use didactic materials in their work, including the active use of onyms: sayings, poems aimed at working out the phonetic component of onyms, as well as any excerpts from literary texts that allow you to analyze the stylistic potential of onyms in literature.

In the course of the study, it was proved that English anthroponyms are, first of all, the object of the study of linguistics, they have a rich linguocultural and stylistic potential that contributes to the general development of the student's personality, his literacy and culture. The study of personal names in English lessons in a secondary school motivates students, is of great practical importance and contributes to the general cultural development of the student's personality. 


\section{Литература}

Cartularium saxonicum: сборник хартий по англосаксонской истории // Johnson Reprint Corporation. - 1964. - 696 c.

Виндт Б. Обзор литературной ономастики в контексте теории литературы // Onoma: Journal of the International Council of Onomastic Sciences (Leuven). - 2005. - C. 40, 43-63.

Гарагуля С.И. Антропонимия в лингвокультурном и исторических аспектах. - Книжный дом ЛИБРОКОМ, 2010. - 126 с.

Горбаневский М.В. В мире имен и названий / М. В. Горбаневский. - М.: Знание, 1987. - 156 с.

Мадиева Г.Б., Супрун В.И. Теоретические основы ономастики. - Алматы: Арыс; Волгоград: Перемена, 2011. - 280 с.

Мордвинова Н.Г. Словесные товарные знаки алкогольных напитков: на материале русского, чувашского, французского, итальянского, испанского, немецкого и английского языков (кандидатская диссертация). - Чебоксары, 2008. Retrieved from http://www.dissercat.com/content/slovesnye-tovarnye-znaki-alkogolnykh-napitkov-na-materiale-russkogo-chuvashskogo-frantsuzsko

Оксфордский словарь идиом / Под редакцией Дж. Сифринга. - Оксфорд: Издательство Оксфордского университета. 2004. $-340 \mathrm{c}$.

Подольская Н.В. Словарь русской ономастической терминологии. - М.: Наука. 1988. - 192 с.

Салимова Д.А. Антропонимия романов Д.И. Стахеева / Д.А. Салимова, Г.Р. Патенко. - Елабуга: Изд-во Елабуж. госпедуниверс., 2008. - 112 с.

Саттаров Г.Ф. Татарская антропонимика / Г. Ф. Саттаров. - Казань: ТКИ, 1992. - 240 с.

Сирл У.Г. Ономастика. Англосаксонизм: Список англосаксонских имен собственных со времен / Cambridge University Press. $-2011 .-662 \mathrm{c}$.

Суперанская А.В. Что такое топонимика? /А. В. Суперанская. - М.: Наука, 1984. - 182 с.

Суперанская А.В. Общая теория имени собственного. - М.: Издательство ЛКИ, 2007. - 367 с.

Эквалл Э. Ранние лондонские личные имена. - Швеция: Лунд, 1947. - 207 с.

Gasque Th. Дж. Американское общество имен и международная ономастика // Onoma: Journal of the International Council of Onomastic Sciences (Leuven). - 2010. - C. 45, 87-106.

Trademarks // The virtual patent office Bohemia Patent, 1998. Retrieved from http://www.patent.cz/english/i_tm.htm

\section{References}

Birch W. de Gray. (1964) Cartularium-saxonicum: a collection of charters relating to Anglo-Saxon History. Johnson Reprint Corporation, $696 \mathrm{p}$.

Ekwall E. (1947). Early London Personal Names. Sweden: Lund, 207 p.

Gasque Th. J. (2010). The American name society and international onomastics. Onoma: Journal of the International Council of Onomastic Sciences (Leuven), Vol 45. 87-106 p.

Garagulya S. I. (2010). Antroponimiya v lingvokul'turnom i istoricheskikh aspektakh [Anthroponymy in linguocultural and historical aspects]. Knizhnyy dom LIBROKOM, 126 p. (in Russian)

Gorbanevsky M. V. (1987) V mire imen i nazvanii [In the world of names]. M.V. Gorbanevsky. Moscow: Znanie, 156 p. (in Russian)

Madieva G.B., Suprun V.I. (2011). Teoreticheskie osnovy onomastiki [The Theoretical Fundamentals of Onomastics]. Almaty: Arys; Volgograd: Peremena, 280 p. (in Russian)

Mordvinova N.G. (2008). Slovesnye tovarnye znaki alkogol'nyh napitkov: na materiale russkogo, chuvashskogo, francuzskogo, ital'yanskogo, ispanskogo, nemeckogo i anglijskogo yazykov (Candidate dissertation) [Verbal trademarks of alcoholic drinks: on the material of Russian, Chuvash, French, Italian, German and English languages]. Cheboksary. Retrieved from http://www.dissercat. com/content/slovesnye-tovarnye-znaki-alkogolnykh-napitkov-na-materiale-russkogo-chuvashskogo-frantsuzsko (in Russian)

Podolskaya N.V. (1988). Slovar' russkoj onomasticheskoe terminologii [Dictionary of Russian Onomastic Terminology]. M.: Nauka, 192 p. (in Russian)

Salimova D.A. (2008). Antroponimiya romanov D.I. Stakheeva [Anthroponymy of D.I. Staheev's novels]. D.A. Salimova, G.R. Patenko. Yelabuga: Yelabuga State Pedagogical University publishing house, 112 p. (in Russian)

Sattarov G. F. (1992). Tatarskaya onomastika [Tatar onomastics]. G.F. Sattarov. Kazan: TKI, 240 p. (in Russian)

Searle W. G. (2011). Onomasticon Anglo-Saxonicum: A List of Anglo-Saxon Proper Names from the Time of Beda to That of King John. Cambridge: Cambridge University Press, 662 p.

Siefring J. (2004). Oxford Dictionary of Idioms. Oxford: Oxford University Press, 340 p. sian)

Superanskaya A.V. (1984). Shto takoe toponimika [What is toponymy?]. A.V. Superanskaya. Moscow: Nauka, 182 p. (in Rus-

Superanskaya A.V. (2007). Obshchaya teoriya imeni sobstvennogo [General Theory of Proper Names]. M.: Izdatel'stvo LKI, 367 p. (in Russian)

Trademarks. (1998). The virtual patent office Bohemia Patent. Retrieved from http://www.patent.cz/english/i_tm.htm

Windt B. (2005). An overview of literary onomastics in the context of literary theory. Onoma: Journal of the International Council of Onomastic Sciences (Leuven). Vol. 40. 43-63 p. 